56 Melander $\mathrm{H}$, Salmonson $\mathrm{T}$, Abadie $\mathrm{E}$, van Zwieten-Boot B. A regulatory apologia - a review of placebo-controlled studies in regulatory submissions of new-generation antidepressants. Eur Neuropsychopharmacol 2008; 18 : 623-7.

57 Broich K. Committee for Medicinal Products for Human Use (CHMP) assessment on efficacy of antidepressants. Eur Neuropsychopharmacol 2009; 19: 305-8.

58 National Institute for Health and Clinical Excellence. Agomelatine for the Treatment of Major Depressive Episodes (Terminated Appraisal). NICE, 2011 (http://www.nice.org.uk/nicemedia/live/13539/55586/55586.pdf).
59 Novartis. Financial Report Q3 2011. Novartis, 2011 (http://www.novartis com/downloads/investors/financial-results/quarterly-results/q3-2011-mediarelease-en.pdf).

60 European Medicines Agency. What Benefit has Valdoxan Shown During the Studies? European Medicines Agency, 2012 (http://www.ema.europa.eu/ ema/index.jsp?curl = pages/medicines/human/medicines/000915/human med_001123.jsp\&mid = WC0b01ac058001d124\&jsenabled = true).

61 Gøtzsche PC. Why we need easy access to all data from all clinical trials and how to accomplish it. Trials 2011; 12: 249.

\title{
Frantz Fanon's Black Skin, White Masks
}

\section{Roland Littlewood}

Fanon's Peau Noire, Masques Blancs, the 1952 revision of his (rejected) doctoral thesis, strikes the native English speaker as unduly epigrammatic and poetic, yet its impassioned denunciation of racism and colonialism is replete with citations of Sartre and Merleau-Ponty, Hegel and Marx, Jaspers and Anna Freud.

Fanon was born in 1928 into a comfortable middle-class Creole family in the West Indian island of Martinique, then a French colony and now a département of France. Fighting for the Free French forces in the Second World War, afterwards he proceeded to Lyons to study medicine. Appointed in 1953 as a consultant psychiatrist in French Algeria, then about to commence its war of liberation from the metropolis, Fanon supported the Algerian resistance while continuing to practise medically, and wrote articles on the effects of torture and atrocity on the local civilian population, but also on the French military. He resigned from his post to join the rebel F.L.N. headquarters in Tunis, and in 1960 was appointed ambassador from the provisional Algerian government to Nkrumah's Ghana. He died of leukaemia the following year.

The 1952 book had taken a more restricted look at the psychodynamic effects of colonisation on the character and actions of Black Caribbeans, both in the islands and after migration to Europe. Influenced by Sartre's Anti-Semite and Jew, and reacting against Octave Mannoni's thesis that the colonial subject develops an inevitable psychological dependence on the coloniser, Fanon argued that West Indians had been stripped of their authenticity by first slavery and later imperialism. The French now proclaimed that the colonised, like Fanon himself, could become truly French (évolué) and take their place in the metropolis, but at the same time in subtle and not-so-subtle ways made it evident that this was quite impossible. Dramatically tracing the effect of racist stereotypes on daily life and on sexual and family relations, Fanon examines the European image of the Black as crudely physical, oversexed and intellectually impoverished, through using clinical case histories, memoirs and novels, government documents and psychoanalytical theories. The Creole response is 'lactification', a hopeless attempt to become as European as possible in education, taste and thought; just as the Whites become transformed through their own racism.

Frantz Fanon's argument and style influenced me as a junior psychiatrist in my first book Aliens and Alienists written with Maurice Lipsedge, and later when as an anthropologist, I lived with a new Trinidadian religion for a couple of years: away from an ethnic essentialism, he showed me how conflicting groups can mutually constitute each other in a perverse embrace under a political power which is generally held by one side alone. We are all creolised.

What is the relevance of Fanon today? Europe's empires have apparently fallen but in our globalised (a.k.a. neoliberal) world, domination and power have hardly shifted their focus: the colonised are now more likely to be located in the metropole as well as in the global marketplace, while they still seek their identity through simulacra of the oppressors; as we, the beneficiaries, pursue our phantasmal desires at their expense. I particularly respond to his comments on the French colonial attempt to divest Algerian women of the haik (veil): yes, said Fanon, but not yet, and not at the bequest of the European - but by themselves, in their own time, and at their own wish. 